\title{
Comparative assessment of the antibacterial profile of Onion (Allium cepa) and Garlic (Allium sativum) against Pseudomonas aeruginosa, Staphylococcus aureus and Candida albicans
}

\author{
Akubuenyi Felix Chinedu
}

Department of Microbiology, Cross River University of Technology, Calabar, Cross River State, Nigeria.

*E-mail: felixakubuenyi@gmail.com; Tel. +2348035008093

Accepted 24t ${ }^{\text {st }}$ December, 2019

\begin{abstract}
Aqueous and ethanol extracts of onion and garlic were evaluated for antibacterial susceptibility profile using disc dilution method. Each extract was evaluated at concentrations of $100 \%, 50 \% 25 \%$ and $12.5 \%$ against three common bacterial opportunistic pathogens (Pseudomonas aeruginosa, Staphylococcus aureus and Candida albicans). Result showed that Pseudomonas aeruginosa and Staphylococcus aureus strain had 25\% sensitivity in onion aqueous extract while Candida albicans was resistant to it. Candida albicans showed $25 \%$ sensitivity in onion ethanol extract while Pseudomonas aeruginosa and Staphylococcus aureus were resistant to it. Both Pseudomonas aeruginosa and Staphylococcus aureus demonstrated $75 \%$ sensitivity to concentrations of aqueous garlic extract, with Candida albicans having $50 \%$ sensitivity. Result findings revealed that garlic aqueous extract had the highest antibacterial effect on test organisms, which indicates that it could be used in the treatment of diseases associated with the organisms; Pseudomonas aeruginosa, Staphylococcus aureus and Candida albicans. This explains the basis for the use of these extracts in traditional medicine.
\end{abstract}

Keywords: Antimicrobial profile, Allium cepa, Allium sativum, Opportunistic bacteria and traditional medicine.

\section{Introduction}

Medicinal plants are of great importance to the health of individuals and communities in general. The antimicrobial activities of such plant extracts have been linked to the presence of bioactive compounds which sometimes serve to protect the plants themselves against bacteria, fungi and viral infections as well as exhibiting their antimicrobial properties on these organisms (ElMahmood et al., 2007). Allium is the largest and most important representative of the Liliaceae family comprises of 450 species. Onion (Allium cepa) is a bulbous plant widely cultivated in almost every country of the world (Hannan et al., 2010). It is rich in proteins, carbohydrates, sodium, potassium and phosphorus (Lampe,
1999). It is among the oldest cultivated plants used both as food and for medicinal applications (Lanzotti, 2006). Onion bulbs contain a good number of phytochemicals, most of which are hydrocarbons and their derivatives. These secondary metabolites include; tannins, terpenoids, alkaloids, flavonoids allins, steroid saponins, polysaccharides fructosans, saccharose and other sugars, which have been found in-vitro to have antioxidant, antibacterial and anti-inflammatory properties (Cowan, 2001).

Onion is documented to have anti-pathogenic (ShamsGhahfarokli et al., 2006; Irkin and Arslan, 2010), anticancer (Kodali et al., 2015), anti-diabetic (Hague et al., 
2011), anti-depressant (Jaouad, 2010), cardio protective (Park et al., 2009) and hepatoprotective (Adaramoye, 2009) activities. Shams-Haidari et al., (2008) deposited that serum uric acid levels significantly lowered on administration of onion to artificially induced hyperuricemic rats. Singh et al., (2009) reported that the peels of red onion had excellent antioxidant and antimutagenic ability which was due to its high concentration of polyphenolic compounds.

Garlic (Allium sativum) is classified as a member of family Alliaceae (Huzaifa et al., 2014). It is a bulbous plant that produces hermaphrodite flowers, and pollinated by bees and other insects. Research reported that it may be originally native to Asia, but has long been naturalized to Europe northern Africa, Mexico and all over the world (Daka, 2011). Garlic has anti-bacterial, anti-viral, antifungal, anti-protozoal, anti-cancer, anti-oxidant, immunomodulatory, anti-inflammatory, hypoglycemic and hypocholesterolemic effect (Rehman and Munir, 2015; Shaloo et al., 2015). The herbal medicine may be in the form of powders, liquid or mixtures which may be raw or boiled, ointments linings and incision (Jehan et al., 2011).

Phytochemical screening of Garlic by different researchers have revealed the presence of saponin, flavonoids, alkaloids, terpenoid, tannins, phlobutanin, ketone, amino acid and protein, volatile oil and cardiac glycosides (Arify et al., 2018; Igra and Zikhi, 2019). Flavonoids have antioxidant activities as well as much health promoting effects viz., anti-allergic, anti-cancer, anti-oxidant, anti-inflammatory, anti-thrombotic, vasoprotective, tumour inhibitory, antimicrobial and antiviral properties (Trease and Evans, 2002). They act on bacteria by inhibiting its protein synthesis (Hong-xi and Song, 2001). The presence of alkaloids in Garlic aqueous bulb extract shows the potential of the extract to have analgesic, antiinflammatory and adaptogenic effects, which helps the host (man and animal) to develop resistance against diseases and endurance against stress (Gupta, 1994).

\section{MATERIALS AND METHODS}

\section{Collection of samples}

Allium cepa (onion) and Allium sativum (garlic) were obtained from Watt market, Calabar, Nigeria, and they were of analytical standard.

\section{Test organisms}

Multidrug resistance bacteria; Pseudomonas aeruginosa, Staphylococcus aureus, and Candida albicans were isolated from patients' wounds at the University of Calabar Teaching Hospital (UCTH) Calabar, Nigeria.

\section{Extraction of Allium cepa and Allium sativum}

The onion bulbs were washed with sterile distilled water repeatedly. The outer covering of the bulb was manually peeled off and fleshy part was re-washed with sterile distilled water. The onion bulb was sliced and blended. A $130.4 \mathrm{~g}$ (65.2g for aqueous and $65.2 \mathrm{~g}$ for ethanolic extraction) of paste was pressed using muslin cloth. The fresh onion juice was immediately analyzed for its antibacterial activity.

Fresh garlic were thoroughly washed with sterile distilled water. They were cut into pieces to allow easy blending. Exactly $56.8 \mathrm{~g}$ (28.4g for aqueous and $28.4 \mathrm{~g}$ for ethanolic extraction) of the blended garlic was pressed using muslin cloth to form juice. The fresh garlic juice was immediately analyzed for its antibacterial activity.

\section{Preparation of Whatman filter paper discs}

This was done by placing $2 \mathrm{ml}$ of the stack extract $(100 \%)$ in the first tube, while each of the other three tubes was served with $1 \mathrm{ml}$ of distilled water each. Later, $1 \mathrm{ml}$ was transferred from tube 1 to tube $2,1 \mathrm{ml}$ from tube 2 to tube 3 and finally, $1 \mathrm{ml}$ from tube 3 to tube 4 , giving concentrations of $100 \%, 50 \%, 25 \%$ and $12.5 \%$ respectively. This method was used for each of the extracts (i.e; onion aqueous, onion ethanolic, garlic aqueous and garlic ethanolic). Each transfer was followed by thorough and gentle shaking to allow for homogenous mixing of contents. Next, filter paper discs already prepared were suspended (soaked) in each of the tubes and allowed to stay for 24 hours, to enable the discs absorb the ingredients of the extracts. Thereafter, the discs were brought out on trays and dried in the oven at $60^{\circ} \mathrm{C}$ for 10 minutes. After drying, they were brought out of the oven, into their respective sterile containers in readiness for antibacterial sensitivity testing (Kirby-Bauer et al., 1996).

\section{Antibacterial susceptibility testing of Allium cepa and Allium sativum against selected bacterial isolates}

The antibacterial susceptibility profile was determined using disc diffusion method (Kirby-Bauer et al., 1996). In this method, sterilized Petri-dishes were set out on the bench and the plates labeled accordingly with their respective bacterial isolate. Then, $1 \mathrm{ml}$ of each broth culture of the three isolates was placed on separate plates using three sterile pipettes. Next, Mueller Hinton agar (already sterilized) and held at a temperature of $45-$ $55^{\circ} \mathrm{C}$ was poured into each of the plates and the plates shaken back and forth (swirling) for the contents of the Petri-dishes to mix thoroughly. The plates were then allowed to stand for 30-45 minutes in order to solidify. After solidification, filter paper discs carrying various 
Table 1. Antibacterial susceptibility profile of aqueous extract of Onion.

\begin{tabular}{lllllll}
\hline Isolates & $\begin{array}{l}\mathbf{1 0 0} \% \\
(\mathbf{m m})\end{array}$ & $\begin{array}{l}\mathbf{5 0 \%} \\
(\mathbf{m m})\end{array}$ & $\begin{array}{l}\mathbf{2 5 \%} \\
(\mathbf{m m})\end{array}$ & $\begin{array}{l}\mathbf{1 2 . 5} \\
(\mathbf{m m})\end{array}$ & $\begin{array}{l}\text { Control } \\
(\boldsymbol{\mu g} / \mathbf{m l}) \\
(\mathbf{m m})\end{array}$ & $\%$ Sensitivity \\
\hline Pseudomonas aeruginosa & $6(\mathrm{R})$ & $23(\mathrm{~S})$ & $6(\mathrm{R})$ & $6(\mathrm{R})$ & $30(\mathrm{~S})$ & 25 \\
Staphylococcus aureus & $21(\mathrm{~S})$ & $6(\mathrm{R})$ & $6(\mathrm{R})$ & $6(\mathrm{R})$ & $25(\mathrm{~S})$ & 25 \\
Candida albicans & $6(\mathrm{R})$ & $6(\mathrm{R})$ & $6(\mathrm{R})$ & $6(\mathrm{R})$ & $35(\mathrm{~S})$ & 0 \\
$\%$ Susceptibility & 33.3 & 33.3 & 0 & 0 & & \\
\hline
\end{tabular}

Ciprofloxacin (CPX) 10 $\mu \mathrm{g} / \mathrm{ml}$, broad-spectrum for both Gram positive and Gram negative bacteria.

$R \leq 7 \mathrm{~mm} ; \quad S \geq 8 \mathrm{~mm}$

Table 2. Antibacterial susceptibility profile of ethanol extract of Onion

\begin{tabular}{lllllll}
\hline Isolates & $\begin{array}{l}\mathbf{1 0 0} \% \\
(\mathbf{m m})\end{array}$ & $\begin{array}{l}\mathbf{5 0 \%} \\
(\mathbf{m m})\end{array}$ & $\begin{array}{l}\mathbf{2 5 \%} \\
(\mathbf{m m})\end{array}$ & $\begin{array}{l}\mathbf{1 2 . 5 \%} \\
(\mathbf{m m})\end{array}$ & $\begin{array}{l}\text { Control } \\
(\boldsymbol{\mu g} / \mathbf{m l}) \\
(\mathbf{m m})\end{array}$ & $\begin{array}{l}\% \\
\text { Sensitivity }\end{array}$ \\
\hline Pseudomonas aeruginosa & $6(\mathrm{R})$ & $6(\mathrm{R})$ & $6(\mathrm{R})$ & $6(\mathrm{R})$ & $31(\mathrm{~S})$ & 0 \\
Staphylococcus aureus & $6(\mathrm{R})$ & $6(\mathrm{R})$ & $6(\mathrm{R})$ & $6(\mathrm{R})$ & $25(\mathrm{~S})$ & 0 \\
Candida albicans & $6(\mathrm{R})$ & $6(\mathrm{R})$ & $6(\mathrm{R})$ & $15(\mathrm{~S})$ & $23(\mathrm{~S})$ & 25 \\
\% Susceptibility & 0 & 0 & 0 & 33.3 & & \\
\hline
\end{tabular}

Ciprofloxacin (CPX) 10 $\mathrm{gg} / \mathrm{ml}$, broad-spectrum for both Gram positive and Gram negative bacteria.

$\mathrm{R} \leq 7 \mathrm{~mm} ; \quad \mathrm{S} \geq 8 \mathrm{~mm}$

Table 3. Antibacterial susceptibility profile of aqueous extract of Garlic

\begin{tabular}{lllllll}
\hline Isolates & $\begin{array}{l}\mathbf{1 0 0 \%} \\
(\mathbf{m m})\end{array}$ & $\begin{array}{l}\mathbf{5 0 \%} \\
(\mathbf{m m})\end{array}$ & $\begin{array}{l}\mathbf{2 5 \%} \\
(\mathbf{m m})\end{array}$ & $\begin{array}{l}\mathbf{1 2 . 5 \%} \\
(\mathbf{m m})\end{array}$ & $\begin{array}{l}\text { Control } \\
(\boldsymbol{\mu g} / \mathbf{m l}) \\
(\mathbf{m m})\end{array}$ & $\%$ Sensitivity \\
\hline Pseudomonas aeruginosa & $25(\mathrm{~S})$ & $23(\mathrm{~S})$ & $6(\mathrm{R})$ & $25(\mathrm{~S})$ & $30(\mathrm{~S})$ & 75 \\
Staphylococcus aureus & $30(\mathrm{~S})$ & $35(\mathrm{~S})$ & $25(\mathrm{~S})$ & $6(\mathrm{R})$ & $33(\mathrm{~S})$ & 75 \\
Candida albicans & $27(\mathrm{~S})$ & $28(\mathrm{~S})$ & $6(\mathrm{R})$ & $6(\mathrm{R})$ & $29(\mathrm{~S})$ & 50 \\
\% Susceptibility & 100 & 100 & 33.3 & 33.3 & & \\
\hline
\end{tabular}

Ciprofloxacin (CPX) 10 $\mathrm{g} / \mathrm{ml}$, broad-spectrum for both Gram positive and Gram negative bacteria.

$\mathrm{R} \leq 7 \mathrm{~mm} ; \quad \mathrm{S} \geq 8 \mathrm{~mm}$

concentrations of the extracts such as $100,50,25$ and $12.5 \%$ including the control (Ciprofloxacin) were transferred to appropriate locations on the agar plates with the help of sterile forceps. The plates were then incubated at $37^{\circ} \mathrm{C}$ for 24 hours. At the end of incubation, zones of inhibition (for sensitive isolates) or no inhibition (for resistant isolates) were measured and recorded in millimeters.

\section{Determination of Minimum Inhibitory Concentration (MIC) of extracts}

The MIC of the fresh onion and garlic juice against the test bacteria was determined using the broth dilution method. One (1.0) $\mathrm{ml}$ of the juice was added to $1 \mathrm{ml}$ of nutrient broth and subsequently transferred. One (1.0) $\mathrm{ml}$ from the first test tube to the next, for up to the seventh test tube. Then $1 \mathrm{ml}$ of standardized 18hrs broth culture of test organism $(1.0 \times 106 \mathrm{CFU} / \mathrm{ml})$ was inoculated into each test tube and thoroughly mixed on a vortex mixer.
The test tubes were then incubated at $37^{\circ} \mathrm{C}$ for $24 \mathrm{hrs}$. The tube with of the lowest dilution with no detectable growth was considered as the Minimum Inhibitory Concentration.

\section{RESULTS}

The result of the antibacterial sensitivity profile of aqueous extract of onion (Table 1) showed that Pseudomonas aeruginosa and Staphylococcus aureus were $25 \%$ sensitive to aqueous extract of onion while Candida albicans was resistance to all the concentrations of the extract. All text organisms were sensitive to the control. The test organisms demonstrated resistance to most concentrations of ethanolic extract of onion except Candida albicans which was $25 \%$ sensitive as shown in Table 2.

The aqueous extract of garlic demonstrated high efficacy against test organisms (Table 3), with Pseudo- 
Table 4. Antibacterial susceptibility profile of ethanol extract of Garlic

\begin{tabular}{lllllll}
\hline Isolates & $\begin{array}{l}\mathbf{1 0 0 \%} \\
(\mathbf{m m})\end{array}$ & $\begin{array}{l}\mathbf{5 0 \%} \\
\mathbf{m m})\end{array}$ & $\begin{array}{l}\mathbf{2 5 \%} \\
(\mathbf{m m})\end{array}$ & $\begin{array}{l}\mathbf{1 2 . 5 \%} \\
(\mathbf{m m})\end{array}$ & $\begin{array}{l}\text { Control } \\
(\boldsymbol{\mu g} / \mathbf{m l}) \\
(\mathbf{m m})\end{array}$ & $\%$ Sensitivity \\
\hline Pseudomonas aeruginosa & $6(\mathrm{R})$ & $6(\mathrm{R})$ & $6(\mathrm{R})$ & $6(\mathrm{R})$ & $30(\mathrm{~S})$ & 0 \\
Staphylococcus aureus & $6 \mathrm{R})$ & $6(\mathrm{R})$ & $6(\mathrm{R})$ & $6(\mathrm{R})$ & $28(\mathrm{~S})$ & 0 \\
Candida albicans & $6(\mathrm{R})$ & $13(\mathrm{~S}$ & $6(\mathrm{R})$ & $6(\mathrm{R})$ & $23(\mathrm{~S})$ & 25 \\
$\%$ Sensitivity & 0 & 33.3 & 0 & 0 & & \\
\hline
\end{tabular}

Ciprofloxacin (CPX) $10 \mu \mathrm{g} / \mathrm{ml}$, broad-spectrum for both Gram positive and Gram negative bacteria.

$R \leq 7 \mathrm{~mm} ; \quad S \geq 8 \mathrm{~mm}$

Table 5. Minimum Inhibitory Concentration (MIC) of onion aqueous extract

\begin{tabular}{lll}
\hline Isolates & MIC $(\mu \mathrm{g} / \mathrm{ml})$ & MBC $(\mu \mathrm{g} / \mathrm{ml})$ \\
\hline Pseudomonas aeruginosa & 25.0 & 50.0 \\
Staphylococcus aureus & 6.25 & 12.5 \\
Candida albicans & 50.0 & 100.0 \\
\hline
\end{tabular}

Table 6. Minimum Inhibitory Concentration (MIC) of onion ethanolic extract

\begin{tabular}{lll}
\hline Isolates & MIC $(\mu \mathrm{g} / \mathrm{ml})$ & MBC $(\mu \mathrm{g} / \mathrm{ml})$ \\
\hline Pseudomonas aeruginosa & 25.0 & 50.0 \\
Staphylococcus aureus & 50.0 & 100.0 \\
Candida albicans & 6.25 & 12.5 \\
\hline
\end{tabular}

Table 7. Minimum Inhibitory Concentration (MIC) of Garlic aqueous extract

\begin{tabular}{lll}
\hline Isolates & MIC $(\mu \mathrm{g} / \mathrm{ml})$ & MBC $(\mu \mathrm{g} / \mathrm{ml})$ \\
\hline Pseudomonas aeruginosa & 1.17 & 3.13 \\
Staphylococcus aureus & 3.13 & 6.25 \\
Candida albicans & 1.57 & 3.13 \\
\hline
\end{tabular}

monas aeruginosa and Staphylococcus aureus recording $75 \%$ sensitivity to different concentrations of the extract while Candida albicans showed $50 \%$ sensitivity to the extract. All the test organisms were $100 \%$ sensitive to $100 \%$ and $50 \%$ concentrations of the extract. Result showed that all the test organisms except Candida albicans (25\%) were resistant to the different concentrations of garlic extract (Table 4).

The Minimum Inhibitory Concentration (MIC) and Minimum Bactericidal Concentration (MBC) analysis of the aqueous extract of onion (Table 5) revealed that the MIC of Pseudomonas aeruginosa, Staphylococcus aureus and Candida albicans was 25.0, 6.25, 50.0ug/ml respectively. The MBC analysis revealed that Pseudomonas aeruginosa, Staphylococcus aureus and
Candida albicans are 50.0, 12.5 and $100.0 \mathrm{ug} / \mathrm{ml}$ respectively. The MIC and MBC value of ethanolic extract of onions are shown on Table 6. Those of aqueous and ethanolic extracts of garlic are shown on Tables 7 and 8 respectively.

\section{DISCUSSION}

This research study revealed that the aqueous extract of garlic had the best antibacterial effect on test organisms; Pseudomonas aeruginosa, Staphylococcus aureus and Candida albicans when compared to the ethanolic extract and the values obtained from both aqueous and ethanol extracts of onion. This could be due to the phytochemical 
Table 8. Minimum Inhibitory Concentration (MIC) of Garlic ethanolic extract

\begin{tabular}{lll}
\hline Isolates & MIC $(\mu \mathrm{g} / \mathrm{ml})$ & MBC $(\mu \mathrm{g} / \mathrm{ml})$ \\
\hline Pseudomonas aeruginosa & 50.0 & 100.0 \\
Staphylococcus aureus & 50.0 & 100.0 \\
Candida albicans & 25 & 50.0 \\
\hline
\end{tabular}

constituents of these plants extracts and their different reactivity, solubility and volatility with organic and aqueous medium. This result corroborates the findings of Oboh and Abula, (1997), which attributed the effectiveness of water (aqueous) extract in inhibiting bacteria to the fact that water is a polar solvent and the phytochemical constituents of garlic such as Sulphur, allinase, persoxidase, myrosinase, allicin, ciral, geraniol, linalool, A-phellandrene and B-phellandere (major components) are very soluble in it, hence retaining most of the antimicrobial (antifungal) properties during the extraction process. In a related study, the antimicrobial properties was attributed to the fact that allicin, the main phytochemical constituent of garlic is volatile and very soluble in ethanol and water, thereby maintains its antimicrobial property in inhibiting some gram positive bacteria and some fungi species (Onyeagba et al., 2004). The significant effect of garlic on Pseudomonas aeruginosa, Staphylococcus aureus and Candida albicans compared with onion is in agreement with the findings of Wolde et al. (2018), which reported that Garlic could be used as an effective antibacterial agent for human pathogenic bacteria. It also corroborates the position of Khan et al., (2007) who observed that garlic is effective against some Gram positive and Gram negative bacteria and some fungi such as Aspergillus niger and Aspergillus flavus. The reduced effectiveness of onion could be attributed to the solubility and volatility of its phytochemical components such as allins, flavonoids, steroid sapronins, tannins, terpenoids, alkaloids, polysaccharides, fructosans, saccharose and other sugars (major components), some of which tend to be lost during the process of extraction especially in organic solvents as explained by Song et al. (2000).

This result is also in line with the findings of Reuter et al. (1996), which deposited that Garlic has been found to inhibit Aerobacter, Aeromonas, Bacillus, Citrella, Citrobacter, Clostridium, Enterobacter, Esherichia, Klebsiella, Lactobacillus, Leuconostoc, Micrococcus, Mycobacteriium, Proteus, Providencia, Pseudomonas, Salmonella, Serratia, Shigella, Staphylococcus, Streptococcus and Vibrio. The combination of garlic with antibiotics led to partial or total synergism (Didry et al., 1992). The antimicrobial activities have been reported to increase with increase in the concentration of extracts (Bakht et al. 2014). Benmalek et al. (2013) reported that Gram positive bacteria are more sensitive to onion extract response than gram negative bacteria. In a separate study, Anuja et al. (2015) had reported that the fresh juices of white onion (Allium cepa) and garlic possess significant antibacterial potency against multidrug resistant bacteria.

Zhou et al. (2011) in a meta-analysis of garlic found decreased rates of gastric cancer associated with garlic intake. In a 2013 meta-analysis of epidemiological studies, Zhou et al. (2013) also observed that garlic intake was associated with decreased risk of prostate cancer. A 2014 meta-analysis of observational and epidemiological studies found out that garlic consumption was associated with a lower risk of stomach cancer in Korean people (Woo et al., 2014). Izzo et al. (2004) concluded that consumption of both garlic and onion may have anticarcinogenic effects on health. Nitric oxide scavenging might be the reason for its anti-carcinogenic activity as identified by Lee et al. (2009). In a study conducted by Fu (2004), it was reported that hot air dried onion powder can strongly inhibit the leukemia cell growth. He also stated that onion could be used in powder form for medicinal purposes.

The result of the Minimum Inhibitory Concentration (MIC) corroborates the findings of Anuja et al. (2015), which deposited that the Minimum Inhibitory Concentration (MIC) of garlic was low, ranging from $1.125-25 \% \mathrm{v} / \mathrm{v}$ and that of white onion was 2.125$50 \% \mathrm{v} / \mathrm{v}$. In a related study, Adesina et al. (2011) reported that the Minimum Inhibitory Concentration (MIC) and the Minimum Bactericidal Concentration (MBC) values of the fresh onion juices against the test bacteria were low ranging from $3.125 \% \mathrm{v} / \mathrm{v}-25.0 \% \mathrm{v} / \mathrm{v}$.

Shams-Ghahfarokhi et al. (2006) reported that aqueous extracts of onion showed dose dependent protective effect against pathogenic yeast and dermatophytes. The extract inhibits the growth of Trichophyton rubrum and $T$. mentagrophytes by affecting their morphology at cellular and subcellular level as it disrupts the cell membranes and other membrane bound structures (Ghahfarokhi et al., 2004). In different studies, onion's protective effect against pathogenic bacteria (Escherichia coli, Pseudomonas sp.) and fungi (Candida, Cryptococcus and Malassezia species.) is in dose dependent manner (Irkin and Arslan, 2010). This antimicrobial activity of onion is also variety dependent as few varieties like green onion have least preventive effect against microbes. Santas et al., (2010) had reported that the ethyl acetate sub-fractions of onion showed prevention against microbes which may be due to the presence of 
flavonoids in these extracts. In another study, it was found that onion inhibits the pro-inflammatory messengers and bacterial growth due to the presence of various organic sulfur compounds (Wilson and Adams, 2007).

The significant growth inhibitions of the test organisms by the plant extracts suggests their possible use in controlling these organisms in disease-causing situations and food spoilage. Furthermore, the easy means of obtaining these extracts especially using water base extraction provides an alternative to antibiotics and artificial preservatives, both of which can be toxic at certain concentrations.

\section{CONCLUSION}

Allium cepa (Onions) and Allium sativum (Garlic) have antibacterial properties against common opportunistic bacteria; Pseudomonas aeruginosa, Staphylococcus aureus and Candida albicans. Aqueous extract of Galic was the most effective, revealing its potential efficiency for the treatment of diseases arising from these organisms. The antibacterial profile of these plant extracts underline their recognition and application as medicinal plants.

\section{REFERENCE}

Adaramoye OA (2009). Comparative effects of vitamin E and kolaviron (a biflavonoid from garcinia kola) on carbon tetrachloride - induced renal oxidation damage in mice. Pak. J. Bio. Sci. 12: 1146-1151.

Adesina GO, Jibo S, Agu VE, Ezrinmidu JO (2011). Antibacterial activity of fresh juice of Allium cepa and Zingiber officinale against multidrug resistant bacteria. Int. J. Pharm. Biosci. 2(2): 289-295.

Anuja S, Zine N, Prabhakar Z (2015). Comparative Study of Allium Cepa, Zingiber Officinale and Allium Sativum for Its Antimicrobial Property. Asian J. Pharm. Technol. Innovation. 3(12). www.asianpharmtech.com.

Arify T, Ezhilvalavan S, Varun A, Sundaresan A, Manimaran K (2018). Qualitative phytochemical analysis of garlic (Allium sativum) and Nilavembu (Andrographis paniculata). Int. J. Chem. Stud. 6(3): 1635-1638.

Bakht J, Khan S, Shafi M (2014). In Vitro antimicrobial activity of Allium cepa (dry bulbs) against Gram positive and Gram negative bacteria and fungi. Pak. J. Pharm Sci. 27(1): 139-45.

Benmalek Y, Yahia OA, Belkebir A, Fardeau ML (2013). Antimicrobial and antioxidant activities of Illicium verum, Crataegus oxyacantha ssp monogyna and Allium cepa red and white varieties. Bioengineered. 4: 244-8.

Cowan M (2001). "Plant products as antimicrobial agents", Clinical microbiology Reviews. 12(4):564-582

Daka D (2011). Antibacterial effect of Garlic (Allium sativum) on Staphylococcus aureus: An in vitro study. Afr. J. Biotechnol. 10: 666-669.

Didry N, Dubreuil L, Pinkas M (1992). Antimicrobial activity of naphthaquinones and Allium extracts combined with antibiotics. Pharmaceutical J. 67:148-151

El-Mahmood AM, Amey JM (2007). In vitro antibacterial activity of Parkia biglobosa (Jacq) root bark extract against some microorganisms associated with urinary infections. Afr. J. Biotechnol. 6(11): 1272-1275

Fu HY (2004). Free radical scavenging and leukemia cell growth inhibitory properties of onion powder treated by different heating processes. J. Food Sc. 69:50-54.
Ghahfarokhi MS, Goodarzi MR, Abyanneh M, Al-Tirahi T, Seyedipour G (2004). Morphological evidence for onion-induced growth inhibition of Trichophyton rubrum and Trychophyton Mentagrophytes. Fitoterapia. 75:645-655.

Gupta SS (1994). Prospects and perspective of natural products in Medicine. Indian J. Pharmacol. 26:1-12.

Hague N, Salm U, Nurunmabi TR, Uddin MJ, Jahangir MFK, Islam SMZ, Kamruzzan M, (2011). Management of type 2 diabetes mellitus by lifestyles, diets and medicinal plants. Pak. J. Bio/Sci. 14:13-24.

Hannan T, Humayun M, Hussain M (2010). Yasir and S. Sikandar, "In vitro antibacterial activity of onion (Allium cepa) against clinical isolates of Vibrio cholera", J. Ayub Med. Coll Abbottabad. 22(2): 160-163.

Hong-Xi XU, Song FL (2001). Activity of plant flavonoids against antibiotic resistant bacteria. Phytother. Res. 15:39-41.

Huzaifa U, Labaran I, Bello AB, Olatunde A (2014). Phytochemical screening of aqueous extraction of Garlic (Allium sativum) bulbs. Report and opinion. 6: 1-4.

Igra N, Rikhi SC (2019). Qualitative phytochemical analysis of Allium sativum (Garlic) and Curcuma longa (Turmeric). J. Entomol. Zool. Stud. 7(1): 545-547.

Irkin R, Arslan M (2010). Effect of onion (Allium cepa) extract on microbiological quality of refrigerated beef meat. J. Muscle Food. 21:308-316.

Izzo AA, Capasso R, Capasso F (2004). Eating garlic and onion. A matter of life or death. Br. J. Cancer Pres. 91:194-194.

Jaouad B (2010). Polyphenols: A new strategy for the prevention and potential treatment of anxiety and depression. Curr. Nutr. Food sci. 6:13-18.

Jehan B, Muhammad T, Huma A, Amjad I, Mohammad S (2011). Effect of different solvent extracted sample of Allium sativum (Linn.) on bacteria and fungi. Afr. J. Biotechnol. 10: 5910-5915.

Khan MN, Munawar MA, Mahmud S, Qureshi AK, Rehman S (2007). Characterization of essential oil of local varieties of Citrus grandis. J. Chem. Soc. Pak. 29 (3): 272-274.

Kirby-Bauer (1996). Antimicrobial sensitivity testing by agar diffusion method. Afr J. Clin. Pathol. 44: 493.

Kodali R, Eslick T, Guy D (2015). "Meta-analysis: Does garlic intake reduce risk of gastric cancer?". Nutr. Canc. 67(1): 1-11.

Lampe J (1999). "Health effects of vegetables and fruits: assessing mechanisms of action in human experimental studies". Am. J. Clin. Nutr. 70: 475- 90.

Lanzotti V (2006). The analysis of onion and garlic. J. Chromatogr. A 11(12): 3-22

Lee JK, Murakami WS, Ohigashi H (2009). Suppressive properties of extracts from Japanese edible plants regarding nitric oxide generation. Asian pacific J. Cancer Prevents. 10:263-272.

Oboh PA, Abula EO (1997). The antimicrobial activities of extracts of Sidium guajava and Citrus aurantifolia. Niger. J. Biotechnol. 8(1): 25-29.

Onyeagba RA, Ugbogu OC, Okeke CU, Iroakasi O (2004). Studies on the antimicrobial effects of garlic (Allium sativum Linn), ginger (Zingiber officinale Roscoe) and lime (Citrus aurantifolia Linn). Afr. J Biotechnol. 3: 552-554.

Park S, Kim MY, Lee DH, Lee SH, Baik EJ, Moon CH, Park SW, Ko EY, Oh SR, Jung YS (2009). Methanolic extract of Onion (Allium cepa) attenuates Ischemia/hypoxia-induced apoptosis in cardimyocytes via antioxidants effects. Eur, J. Nutr. 48:235-442.

Rehman ZU, Munir MT (2015). Effect of garlic on the health and performance of broilers. Open Access J. Veterinaria. 3(1):32-39. 17

Reuter HD, Koch HP, Lawson DL (1996). The Science and therapeutic application of Allium sativum and related spices. $2^{\text {nd }}$ Edition Williams and Wilkins Baltimore, M. D. p. 135-212.

Santas J, Almajano MP, Carbo R (2010). Antimicrobial and antioxidant activities of Crude oil onion (Allum cepa) extracts. Int. J. Food Sci. Technol., 45:403-409.

Shaloo V, Sopreet K, Joginder S, Akshay G (2015). Antibacterial effects of Garlic (Allium sativum L.) extract on different pathogenic and non-pathogenic bacteria. RJPBCS. 6: 1103.

Shams-Ghahfarokhi M, Shokoohamiri MR, Amirragab N, Moghadasi B, Moghadasi B, Ghajari A, Zeini F, Sadeghi G, 
Razzaghi-Abyaneh M (2006). In vitro antifungal activities of Allium cepa, Allium sativam and ketoconazole against some pathogenic yeast and dermatophytes. Fitoterapia. 77: 32-323.

Singh BN, Singh BR, Singh RL Prakash D, Singh DP, Sarma BK, Upadhyay G, Singh HB (2009). Polyphenolics from various extracts/fractions of red onion (Allium sp.) peel with potent antioxidant and antimutagenic activities. Food Chem. Toxicol. 47:1161-1167.

Song HS, Sawamura M, Ito T, Ido A, Ukedo H (2000). Quantitative determination and characteristics flavour of daidai (Citrus aurantium L. var. cyathifera Y. Tanaka) peel oil. J. Flav. Fragr. 15 (5): 323-328.

Trease GE, Evans WC (2002). Phytochemicals. In: Pharmacognosy. 15th ed. Saunders Publishers, London. 42-44, 221- 229, 246- 249, 304-306, 331-332, 391-393.

Wilson EA, Adams B (2007). Antioxidant, anti-inflammatory and antimicrobial properties of garlic and onions. Nutr. Food Sci. 37(3):178-183.
Wolde T, Kuma H, Trueha K, Yabeker A (2018). Anti-bacterial activity of Garlic extract against human pathogenic bacteria. J. Pharmacovigil. 6(1): 2-5.

Woo HD, Park S, Oh K, Kim HJ, Shin HR, Moon HK, Kim J (2014). "Diet and cancer risk in the Korean population: a meta-analysis". Asian Pacific J. Cancer Prevention. 15(19): 8509-19.

Zhou XF, Ding ZS, Liu NB (2013). "Allium vegetables and risk of prostate cancer: evidence from 132,192 subjects". Asian Pacific J. Cancer Prevention. 14(7): 4131-4.

Zhou YZ, Hu W, Liu GJ, Wu TX, Wu XT (2011). "Consumption of large amounts of Allium vegetables reduces risk for gastric cancer in a meta-analysis". Gastroenterology. 141(1): 80-89.

http://www.sciencewebpublishing.net/ijbfs 